\title{
Appendix vermiformis duplex
}

\author{
A. K. KHANNA \\ M.S. \\ Department of Surgery, Institute of Medical Sciences, Banaras Hindu University, Varanasi-221005, India
}

\begin{abstract}
Summary
Duplication of the appendix is rare, and fewer than 100 cases have been reported. A case of double appendix with one caecum is reported with inflammation of both appendices.
\end{abstract}

KEY WORDS: double appendix, inflammation.

\section{Introduction}

Duplication of the alimentary tract is uncommon but duplication of the appendix is rare. Basu et al. (1959), in reporting 28 cases of duplication of the alimentary tract, had no case of appendix duplex. Picoli (1892) reported the first case of apendix duplex in a female patient who had associated anomalies of duplication of the entire large bowel, two uteri with two vaginae, ectopia vesicae and exomphalos. Gupta and Kak (1964) could collect fewer than 50 case reports. Till now fewer than 100 cases have been reported.

\section{Case report}

A 28-year-old male presented with the chief complaint of pain in the umblical region radiating to the right iliac fossa for 3 days, associated with vomiting and diarrhoea. The past history revealed two attacks of a similar nature in the last two years. On examination, the patient was febrile $\left(37.5^{\circ} \mathrm{C}\right)$ and pulse was $90 / \mathrm{min}$. Examination of the abdomen revealed tenderness at McBurney's point with a vague lump in the right iliac fossa. Rectal examination revealed mild tenderness in the right lateral wall. A diagnosis of acute appendicitis with an appendicular mass was made which was supported by finding a polymorphonuclear leucocytosis. The patient was kept on conservative treatment in view of the mass and was discharged after 7 days with advice for appendicectomy after 6 weeks.

The patient was readmitted 6 weeks later. Exploration of the abdomen was performed by a grid-iron incision. An appendix of about $5 \mathrm{~cm}$ length was found in the post-ileal position and appendicetomy was done. As the base of appendix was not at its classical site and was about $1.5 \mathrm{~cm}$ above the end of the taenia coli and its base was at the anterior taenia coli, further exploration was mandatory. There was another appendix, about $12 \mathrm{~cm}$ in length, lying in the retro-caecal position. Appendicectomy was performed. Both appendices were inflammed and this was confirmed on histology. The patient made an uneventful recovery and was discharged 7 days later.

\section{Discussion}

Collins (1955) collected 50,000 specimens of appendices and had only 2 cases of congenital duplication of the appendix. Since then single cases have occasionally been reported, the latest report being by Bonk (1980). Tinckler (1968) recorded a unique case of triple appendix associated with other anomalies of double penis, and ectopia vesicae. This was an incidental finding during the laparotomy for an uretero-ileal conduit.

Waugh (1941) described three types of appendicular duplication: (a) 'double barrelled appendix', with a common muscularis and often a distal communication between the lumen of the two appendices (b) 'bird type paired appendix', where two appendices are symmetrically placed on either side of the ileocaecal valve. All such reported cases have been found in newborn who had associated severe congenital defects. (c) 'Taenia coli' type having a normal appendix at the usual site with another appendix though smaller, on a taenia coli.

Wallbridge (1962) classified duplication of the appendix into three types: Type ' $A$ ': partial duplication of the appendix of various degrees on a single caecum. Type 'B': a single caecum with two completely separate appendices. This is further subdivided into type ' $B_{1}$ ', which is also called 'bird like appendix' due to resemblance of the normal arrangement in birds (where there are two appendices symmetrically placed on either side of the ileocaecal valve); Type ' $B_{2}$ ' also called a 'taenia coli' type where one appendix arises from the usual site on caecum 
with another rudimentary appendix from the caecum almost always along the line of taenia coli at a varying distance from the first. Type ' $C$ ': double caecum, each bearing an appendix.

Our case is of Type ' $B_{2}$ ' variety i.e. 'Taenia coli' variety as one appendix, retrocaecal in position arose from the normal site while the other appendix, smaller in size though not rudimentary was placed on the anterior taenia coli about $1.5 \mathrm{~cm}$ away from the base of normally placed appendix (Fig. 1).

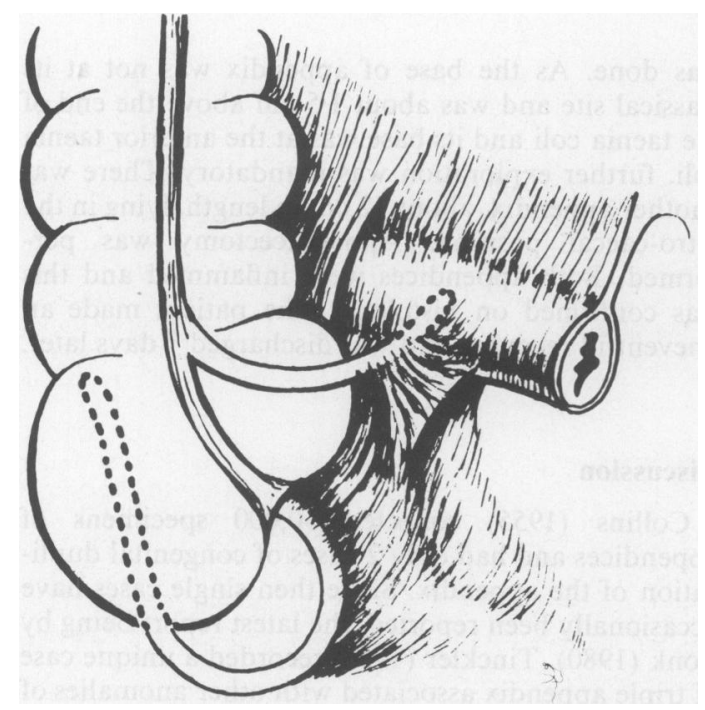

FIG. 1. Appendix vermiformis duplex.

Aetiology of the double appendix is explained by many workers. Kelly and Herdon (1905) considered it to be persistence of a transient appendix appearing in the $10 \mathrm{~mm}$ embryo which normally atrophies. Mitchell (1905) (quoted by Wallbridge) stated it to be a phylogenetic reversion to paired caecal arrangement found in birds. Jones (1912) (quoted by Gupta and Kak) believed that the premammalian caecum was a paired structure which led to obliteration of one caecum in the greater specialization of mammals.

The 'double barrelled' appendix is probably like a tubular duplication similar to those found in the duplication of the gut. The 'bird type' is said to be the mildest possible case of hindgut twinning. The 'taenia coli' type is said to represent the persistence and development of the transient caecal protuber- ance of the 6th embryonic week (Cave, 1936; Waug 1941).

Most of the cases of appendix duplex are of the ' type. Wallbridge (1962) states that out of about reported cases, 30 were of this variety.

Sometimes there is pseudo-duplication which $\frac{\mathrm{C}}{\mathrm{O}-}$ curs because of the previous inflammation leading $\overline{\bar{m}}$ autoamputation and during this process the tip of tige appendix may get attached to a new location of the caecum (Goldschmidt, 1930). Appendix duplex must also be differentiated from a solitary diverticulum of the caecum which is usually situated at the inner angle just above the ileocaecal valve; histologically ă does not contain any lymphoid tissue.

Double appendix is mostly found at the time post-mortem examination or during laparotomy for other reasons but sometimes inflammation of ơ appendix may lead to the diagnosis. Most of the tire both appendices are inflamed but sometimes owe appendix is normal while the other is inflamege (Wallbridge, 1962). Our case had inflammation of both appendices.

\section{References}

Basu, R., Forshall, I. \& Rickham, P.P. (1959) Duplication of th alimentary tract. British Journal of Surgery, 47, 477.

Bonk, U. (1980) Double appendix. Pathology Research and Practi $167,400$.

CAVE, A.J.E. (1936) Appendix vermiformis duplex. Journal Anatomy, 70, 283.

CollLinS, D.C. (1955) A study of 50,000 specimens of the huma vermiform appendix. Surgery, Gynecology and Obstetrics, 10 , 437.

GoLDSCHмIDT, W. (1930) Vergetauschter doppelter wormfortsă․․․․ Zentrablatt für Chirurgie, 57, 3123.

GUPTA, R.C. \& KAK, V.K. (1964) Double appendix. Journal of the Indian Medical Association, 42, 538.

Kelly, H.A. \& HeRDON, E. (1905) Vermiform appendix and diseases. W. B. Saunders, Philadelphia.

Picolı, G. (1892) (Quoted by Gupta and Kak, 1964) Progresim Medico (Napoli), 6, 32.

TINCKLER, L.F. (1968) Triple appendix vermiformis-a unique case British Journal of Surgery, 55, 79.

WALLBRIDGE, P.H. (1962) Double appendix. British Journal \$ิ Surgery, 50, 346.

WaUGH, T.R. (1941) Appendix vermiformis duplex. Archives कु Surgery, 42, 311.

(Accepted 21 May 1982) 